\title{
Modelling seasonal and spatial variations in the surface energy balance of Haut Glacier d'Arolla, Switzerland
}

\author{
Ben W. Brogk, ${ }^{1}$ Ian C. Willis, ${ }^{2}$ Martin J. Sharp, ${ }^{3}$ Neil S. Arnold ${ }^{4}$ \\ ${ }^{1}$ Department of Geography, University of Dundee, Dundee DD1 4HN, Scotland \\ ${ }^{2}$ Department of Geography, University of Cambridge, Downing Place, Cambridge CB2 3EN, England \\ ${ }^{3}$ Department of Earth and Atmospheric Sciences, University of Alberta, Edmonton, Alberta T6G 2E3, Canada \\ ${ }^{4}$ Scott Polar Research Institute, University of Cambridge, Lensfield Road, Cambridge CB2 1ER, England
}

\begin{abstract}
The impact of spatial and temporal variations in the surface albedo and aerodynamic roughness length on the surface energy balance of Haut Glacier d'Arolla, Switzerland, was examined using a semi-distributed surface energy-balance model (Arnold and others, 1996). The model was updated to incorporate the glacier-wide effects of albedo and aerodynamic roughness-length variations using parameterizations following Brock (1997). After the model's performance was validated, the glacier-wide patterns of the net shortwave, turbulent and melt energy fluxes were examined on four days, representative of surface conditions in late May, June, July and August. In the model, meteorological conditions were held constant on each day in order that the impact of albedo and aerodynamic roughness-length variations could be assessed independently. A late-summer snowfall event was also simulated. Albedo and aerodynamic roughness-length variations, particularly those associated with the migration of the transient snowline and the decay of the winter snowpack, were found to exert a strong influence on the magnitude of the surface energy fluxes. The importance of meteorological conditions in suppressing the surface energy fluxes and melt rate following a fresh snowfall was highlighted.
\end{abstract}

\section{INTRODUGTION AND AIMS}

This paper examines the impact of variations in albedo $(\alpha)$ and aerodynamic roughness length $\left(z_{0}\right)$ on spatial and temporal patterns in the modelled surface energy balance of Haut Glacier d'Arolla, Switzerland, during the ablation season. Glacier-wide seasonal variations in $\alpha$ and $z_{0}$, associated with changing surface conditions, were incorporated into the semi-distributed and physically based surface energy-balance model of Arnold and others (1996) using the relationships of Brock (1997). Four modelling experiments were performed with the updated model to address the following specific aims:

1. To assess the accuracy of the updated model in calculating surface melt rates by comparison with measurements of surface lowering at 13 ablation stakes throughout the 1993 ablation season.

2. To examine the impact of the evolution of $\alpha$ and $z_{0}$ on the spatial patterns of the net shortwave, turbulent and melt energy fluxes across the glacier surface at monthly intervals between early and late summer.

3. To assess the impact on the surface energy balance of meteorological conditions and the changes in $\alpha$ and $z_{0}$ associated with summer snowfall events.

4. To examine the combined effects of variations in $\alpha$ and $z_{0}$ and meteorological conditions on the surface energy balance over the course of the ablation season, using time series of data.

\section{BACKGROUND}

The surface melt rate of a snow or ice surface can be calculated from evaluation of the surface energy balance (e.g. Röthlisberger and Lang, 1987). There have been numerous point measurements of glacier surface energy balance (e.g. Hay and Fitzharris, 1988; Braithwaite and Olesen, 1990; Munro, 1990), which have aimed to test and improve energy-balance theory. Several studies have investigated the variation of the energy balance along glacier centre lines, to investigate how glacier mass-balance gradients might respond to climate change (e.g. Oerlemans 1992, 1993; Oerlemans and Fortuin, 1992). However, only rarely have two-dimensional models, which calculate spatial variation in the surface energy balance, been used to calculate variation in melt rates across a glacier (e.g. Munro and Young, 1982; Escher-Vetter, 1985; Arnold and others, 1996; Hock and Noetzli, 1997). These models employ digital terrain models (DTMs) to calculate variation in the shortwave radiation.

As yet, no study has specifically examined spatial and temporal variations in the surface energy balance and melt across an entire glacier throughout an ablation season. The limitations of current two-dimensional energy-balance models prevent such an analysis. First, all the models, except that of Arnold and others (1996), require prescribed values of $\alpha$ for different surface types (e.g. old and new snow, firn, slush and ice) as input to the model, rather than generating them internally. Although this approach is appropriate for "bulk" discharge calculations, it is less suitable for investiga- 


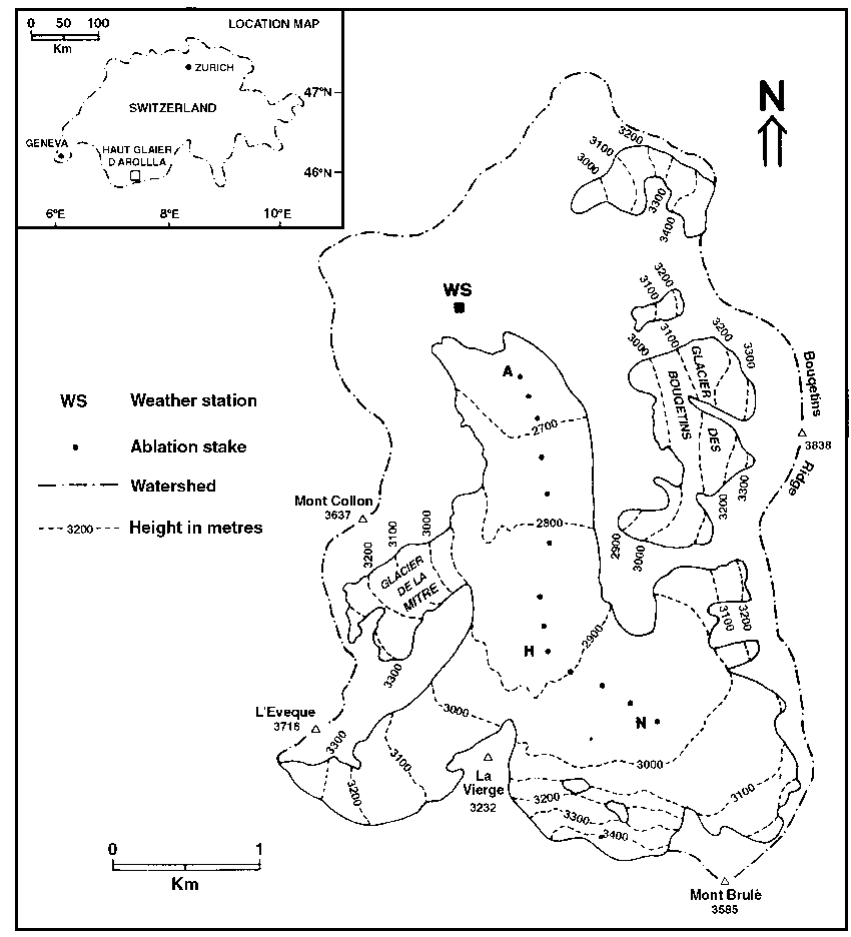

Fig. 1. Site map of Haut Glacier d'Arolla.

tions of spatial and temporal patterns of the energy balance across a glacier. Furthermore, the parameterization scheme used to calculate spatial and temporal $\alpha$ variations within Arnold and others' (1996) model, based on Oerlemans (1992, 1993), is hypothetically rather than physically based. Second, none of the energy-balance models calculates spatial or temporal variations in $z_{0}$, although potentially these can have a large effect on the surface melt rate (Braithwaite, 1995; Hock and Noetzli, 1997). Accurate parameterizations of $\alpha$ and $z_{0}$ variations are required to reflect physical changes in glacier surface conditions over an ablation season.

Modelling of spatial and temporal patterns in the surface energy balance and melt across a glacier is important for a number of reasons: (i) to increase the accuracy of melt and discharge calculations from glacierized basins for hydroelectric power, flood control and water management (Lang, 1986; Willis and Bonvin, 1995); (ii) to make accurate calculations of spatial and temporal variation in surface meltwater inputs to a glacier for studies of glacier hydrology, water quality and dynamics (e.g. Brown and others, 1994; Hubbard and others, 1995; Harbor and others, 1997; Arnold and others, 1998); (iii) to investigate the response of surface melt rates to summer snowfall events and to climate change.

\section{METHODS}

\section{Field site}

Haut Glacier d'Arolla is a $6.3 \mathrm{~km}^{2}$ valley glacier in Valais, Switzerland, with an elevation range of about 2550$3500 \mathrm{~m}$ a.s.l., consisting of an upper basin with northwesterly aspect feeding a glacier tongue flowing to the north (Fig. 1). Steep slopes above $3000 \mathrm{~m}$ a.s.l. and surrounding mountain divides above $3500 \mathrm{~m}$ a.s.l. cast shadows and hence play an important role in the glacier's radiation balance (Arnold and others, 1996). This glacier has been the site of an integrated study of meteorology, hydrology, water quality and dynamics for over 10 years (Richards and others, 1996), and numerous datasets are available.

\section{The original surface energy-balance model}

The surface energy-balance model used in this study is described in detail by Arnold and others (1996), so only the main components of the model are described here. The surface melt rate, $Q_{\mathrm{M}}$, is calculated from:

$$
Q_{\mathrm{M}}=Q^{*}+I^{*}+Q_{\mathrm{S}}+Q_{\mathrm{L}},
$$

where $Q^{*}$ is the net shortwave radiation flux, $I^{*}$ is the net longwave radiation flux and $Q_{\mathrm{S}}$ and $Q_{\mathrm{L}}$ are the turbulent fluxes of sensible and latent heat, respectively. By convention, all fluxes are considered positive when directed towards the surface (e.g. Röthlisberger and Lang, 1987). The values of the energy fluxes are calculated in $20 \mathrm{~m} \times 20 \mathrm{~m}$ gridcells across the glacier surface at an hourly time-step. Heat conduction into the surface layer is not calculated, as this is considered to be a minor energy flux during the ablation season at Haut Glacier d'Arolla (Arnold and others, 1996).

Four main inputs to the model are required: (i) a highresolution DTM of the glacier surface and surrounding basin; (ii) knowledge of solar elevation and azimuth; (iii) variation in snow depth across the glacier surface at the start of the ablation season; and (iv) meteorological data recorded close to the glacier, which are used to compute the components of the energy balance and melt in each gridcell. In the present study, meteorological data were recorded at an automatic weather station (WS in Fig. 1), located at a proglacial site $200 \mathrm{~m}$ from the glacier snout. New snow was assumed to fall if rain was recorded at the meteorological station when the temperature in an individual cell was $\leq 1^{\circ} \mathrm{C}$.

In the model, the direct and diffuse solar radiation recorded on a horizontal plane at the weather station is adjusted for solar incidence and azimuth angles using a geometrical calculation, and for surface aspect and slope using the DTM of the glacier surface. Shading of the glacier surface at different times of day is calculated using the DTM of the surrounding topography. Diffuse radiation was assumed to equal $20 \%$ of the direct solar beam (Oerlemans, 1993). If in shade, a cell receives only diffuse radiation, to which reflected radiation from the surrounding topography is added using a view-factor relationship (Munro and Young, 1982).

Incoming longwave radiation is calculated as the combination of clear sky and cloud emission, following Braithwaite and Olesen (1990). The longwave emission of both sky and clouds is calculated as a function of the air temperature at the meteorological station and the clear sky and cloud emissivities. Cloud cover was not recorded at the weather station, and was instead calculated from an empirical relationship using daily temperature range. No measurements of the influence of the surrounding topography on incoming longwave radiation were available, so this influence was ignored. The outgoing surface longwave radiation was assumed to be always $316 \mathrm{~W} \mathrm{~m}^{-2}$, i.e. that of a "black body" at $0^{\circ} \mathrm{C}$.

\section{Updating the model}

New parameterizations were incorporated into the model to calculate spatial and temporal variations in $\alpha$ and $z_{0}$. The parameterizations were developed using over 500 measurements of $\alpha$ and $z_{0}$ made at sample points distributed across Haut Glacier d'Arolla in September 1992, between May and 
September 1993 and in July and August 1994 (Brock, 1997). A range of surface and meteorological variables were also measured to provide the independent variables on which the $\alpha$ and $z_{0}$ parameterizations were based. At each sample point the snow depth, density and grain-size, and at 36 sample points the solid impurity concentration, were recorded if the surface was snow. If the surface was ice, the percentage surface debris cover was visually assessed using a $0.5 \mathrm{~m}^{2}$ quadrat. At 13 sample points regular measurements of surface lowering were made to derive the accumulated melt. Meteorological variables were monitored continuously throughout the measurement period at the weather station (Fig. 1), and hourly means of $1 \mathrm{~s}$ samples recorded.

Albedo was measured with a Kipp and Zonen CM7B portable albedometer. The $\alpha$ measurements were made within 3 hours of solar noon under cloud-free conditions and in a surface-parallel plane. Under these conditions the pyranometer accuracy was $\pm 2 \%$, and geometrical factors, due to incorrect instrument position and surface microtopography, cause $\alpha$ variations of $\leq 0.02$ (for $\alpha$ ratios in the range 0.0-1.0) (Brock, 1997). Measurements of surface microtopography were used to calculate $z_{0}$ at each sample point using the empirical formula of Lettau (1969), following the methodology of Munro (1990). It is difficult to quantify the errors associated with this method since a comparison with eddy fluctuation $z_{0}$ measurements, which provide the only truly reliable measurements of $z_{0}$, were not available for comparison. The main source of uncertainty is in how representative a point $z_{0}$ measurement is at the fetch scale (hundreds of metres). On snow, which was relatively spatially homogeneous, this uncertainty was small. The one standard deviation range of $z_{0}$ was $0.03-0.10 \mathrm{~mm}$ on earlyseason snow (late May)and $0.58-1.92 \mathrm{~mm}$ on rough snow (late June). For ice the one standard deviation range was $0.92-5.47 \mathrm{~mm}$.

The parameterizations were developed by regressing the dependent variable $\left(\alpha\right.$ or $\left.z_{0}\right)$ on the independent variables using a least-squares procedure. The most explanatory relationships were identified using $r^{2}$ and root-mean-square (rms) error statistics (Equations 2-6; Table 1).

In the updated model, snow $\alpha\left(\alpha_{\mathrm{S}}\right)$ was thus calculated as a logarithmic function of accumulated daily maximum temperatures since the last snowfall (AT) in ${ }^{\circ} \mathrm{C}$, to account for the temporal decrease of $\alpha_{\mathrm{S}}$ associated with increases in grain-size and impurity load in melting snow. Separate relationships were used to calculate $\alpha_{\mathrm{S}}$ on shallow snow $\leq 0.02 \mathrm{~m}$ w.e. deep, which was affected by the $\alpha$ of the underlying ice, and snow $>0.02 \mathrm{~m}$ w.e. deep which was independent of the underlying material:

$$
\begin{aligned}
\text { snow depth } & \leq 0.02 \mathrm{~m} \text { w.e: } \\
\alpha_{\mathrm{S}} & =0.744-0.258 \log _{10} \mathrm{AT}, \\
\text { snow depth } & >0.02 \mathrm{~m} \text { w.e: } \\
\alpha_{\mathrm{S}} & =0.749-0.124 \log _{10} \mathrm{AT} .
\end{aligned}
$$

AT increased from a value of 0 on the day of a snowfall. Snow $\alpha$ was not allowed to vary outside the range $0.20-0.85$, to ensure unrealistic $\alpha_{\mathrm{S}}$ values were not produced. In the updated model, ice $a\left(\alpha_{\mathrm{I}}\right)$ was calculated as a non-linear function of elevation, to account for longitudinal spatial $\alpha$ variation associated with increasing debris cover down-glacier:

$$
a_{\mathrm{I}}=1 /\left(490.915-0.334 h+6.8 \times 10^{-5} h^{2}\right) .
$$

Equations (2) and (3) were very successful at calculating $\alpha_{\mathrm{S}}$
Table 1. Albedo and aerodynamic roughness-length parameterizations: goodness of fit summary statistics

\begin{tabular}{lccccc}
\hline Equation & Dependent variable & $r^{2}$ & rms error & $P$ & $n$ \\
& & $\%$ & & & \\
& & & & & \\
\hline \multirow{2}{*}{ (2) and $(3)$} & $\alpha_{\mathrm{S}}$ & 68.9 & 0.058 & 99.99 & 236 \\
$(4)$ & $\alpha_{\mathrm{S}}$ & 28.4 & 0.066 & 99.99 & 253 \\
$(5)$ & $\ln z_{0 \mathrm{~S}}$ & 83.1 & 0.64 & 99.99 & 179 \\
$(6)$ & $\ln z_{0 \mathrm{SI}}$ & 18.6 & 1.37 & 99.80 & 64 \\
\hline
\end{tabular}

Notes: The rms error for Equations (5) and (6) is in units of $m m$ of $\ln z_{0} . P$ is the confidence level at which the relationship is significant.

variation, while Equation (4) explained a smaller but significant amount of $\alpha_{\mathrm{I}}$ variation (Table 1; Fig. 2).

The variation of $z_{0}$ over snow surfaces was calculated using a relationship which calculated the natural logarithm of snow $z_{0}\left(\ln z_{0 \mathrm{~S}}\right)$ as a non-linear function of AT, to account for increasing snow roughness during snowmelt:

$\ln z_{0 \mathrm{~S}}$

$$
=1.3373\left\{\operatorname{atan}\left[\left(\log _{10} \mathrm{AT}-1.6842\right) / 0.0964\right]\right\}-1.4005 .(5)
$$

No relationship could explain a significant amount of $z_{0}$ variation over ice $\left(z_{0 \mathrm{I}}\right)$. However, to enable the probable range of turbulent-flux magnitude over ice to be calculated, cell ice $z_{0}$ values were generated by sampling randomly from a normal distribution of $\ln z_{0}$ values. The sample distribution was defined by the mean and standard deviation of $\ln z_{0 \mathrm{I}}$, which had values of 0.81 and 0.89 , respectively.

Fresh snowfalls on older snow surfaces were treated implicitly in the snow $\ln z_{0}$ parameterization (Equation (5)). The cell $z_{0}$ following a fresh snowfall on an ice surface was calculated using a separate relationship:

$\ln z_{0}$ following snowfall on an ice surface $\left(\ln z_{0 \mathrm{SI}}\right)$ :

$$
\ln z_{0 \mathrm{SI}}=-1.09+0.915 \log _{10} \mathrm{AT}-6.66 \mathrm{SD},
$$

where SD is snow depth $(\mathrm{m})$. This equation was used to calculate cell $z_{0}$ so long as new snow was present, after which $z_{0}$ returned to the value for ice. The correspondence between $\ln z_{0}$ calculated from Equations (5) and (6) and measured $\ln z_{0}$ was good, although the calculated range was smaller than the true range (Table 1; Fig. 3).

In the model, the original turbulent-flux calculation was

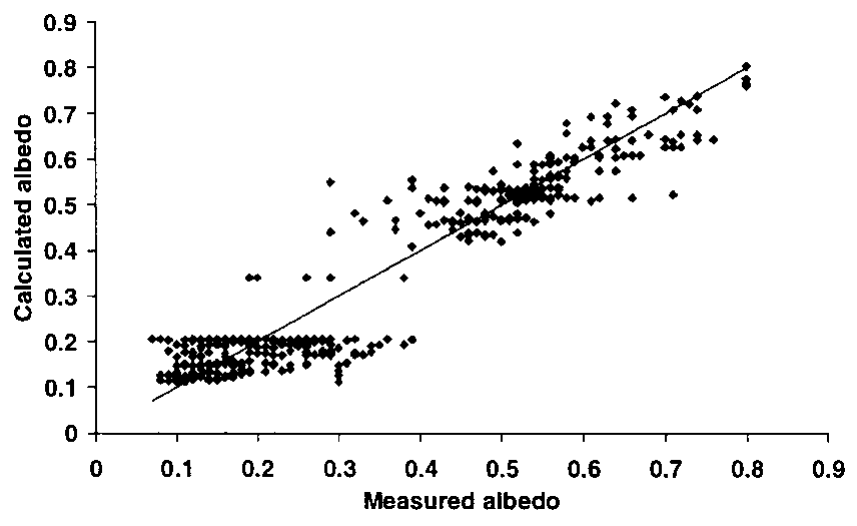

Fig. 2. Comparison of measured snow and ice albedos at Haut Glacier d'Arolla, 1992-94 ablation seasons, and albedos calculated from Equations (2-4). There are 488 data points. The straight line indicates a 1:1 relationship. 


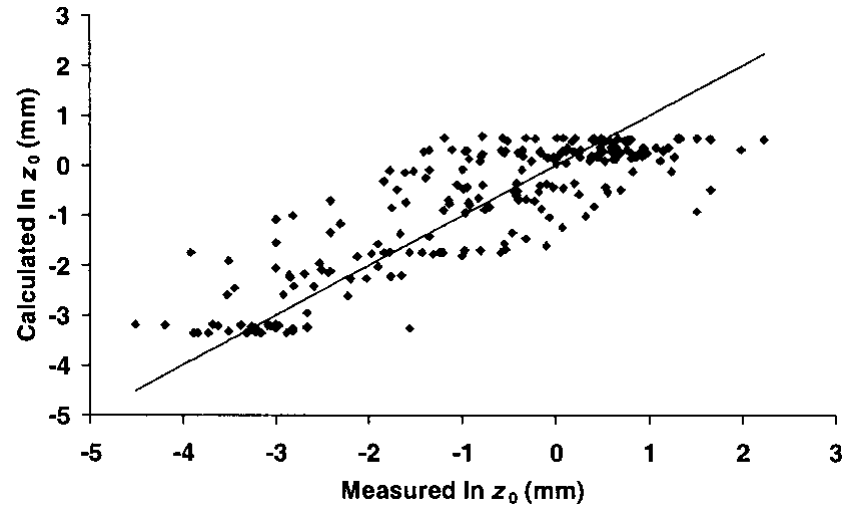

Fig. 3. Comparison of measured aerodynamic roughness lengths over snow at Haut Glacier d'Arolla, 1992-94 ablation seasons, and aerodynamic roughness lengths calculated from Equations (5-6). There are 233 data points. The straight line indicates a 1:1 relationship.

replaced with a "bulk" aerodynamic approach, sensitive to variations in atmospheric stability and $z_{0}$, following Munro (1990). The vertical fluxes of $Q_{\mathrm{S}}$ and $Q_{\mathrm{L}}$ were calculated from cell $2 \mathrm{~m}$ height $z$ air temperature $\left(T_{\mathrm{c}}\right)$ in ${ }^{\circ} \mathrm{C}$, horizontal wind speed $\left(u_{\mathrm{c}}\right)$ in $\mathrm{m} \mathrm{s}^{-1}$ and vapour pressure $\left(e_{\mathrm{c}}\right)$ in $\mathrm{Pa}$. It was assumed that the surface was always melting. Cell temperature was calculated using an atmospheric lapse rate of $6.5^{\circ} \mathrm{C}$ per $1000 \mathrm{~m}$, whereas wind speed was assumed constant for all cells. Cell air pressure was calculated using a lapse rate of $10 \mathrm{kPa}$ per $1000 \mathrm{~m}$, from $100 \mathrm{kPa}$ at sea level. To account for the effects of atmospheric stability in the surface layer, integrated stability functions were introduced into the vertical-flux equations (Dyer, 1974):

$$
\begin{aligned}
& Q_{\mathrm{S}}=\frac{\rho c_{\mathrm{P}} k^{2} u_{\mathrm{c}} T_{\mathrm{c}}}{\left[\ln \left(\frac{z}{z_{0}}\right)+a_{\mathrm{M}}\left(\frac{z}{L}\right)\right]\left[\ln \left(\frac{z}{z_{t}}\right)+a_{\mathrm{M}}\left(\frac{z}{L}\right)\right]}, \\
& Q_{\mathrm{L}}=\frac{\rho \varepsilon L_{\mathrm{v}} k^{2} u_{\mathrm{c}}\left(e_{\mathrm{c}}-e_{\mathrm{S}}\right) / p_{\mathrm{c}}}{\left[\ln \left(\frac{z}{z_{0}}\right)+a_{\mathrm{M}}\left(\frac{z}{L}\right)\right]\left[\ln \left(\frac{z}{z_{\mathrm{e}}}\right)+a_{\mathrm{M}}\left(\frac{z}{L}\right)\right]},
\end{aligned}
$$

where $\rho$ is the air density $\left(\mathrm{kg} \mathrm{m}^{-3}\right), c_{\mathrm{P}}$ is the specific heat capacity of air at constant pressure $\left(\mathrm{J} \mathrm{kg}^{-1}\right), k$ is the von Kármán constant $(0.40), \varepsilon$ is the ratio of the molecular weight of water vapour to air (0.622), $L_{\mathrm{v}}$ is the latent heat of vaporisation $\left(\mathrm{J} \mathrm{kg}^{-1}\right), e_{\mathrm{S}}$ is the vapour pressure at the surface $(\mathrm{Pa}), p_{\mathrm{c}}$ is the atmospheric pressure and $a_{\mathrm{M}}$ is a stability correction constant, for which a value of 5, following Dyer (1974), was used. Similarity between $z_{0}$ and the scalar roughness lengths for temperature and humidity, $z_{\mathrm{t}}$ and $z_{\mathrm{e}}$, respectively, was

Table 2. Daytime mean incoming shortwave radiation and 24 hour means of air temperature, relative humidity and wind speed under high-, medium-and low-energy weather types

\begin{tabular}{lcccc}
\hline Weathertype & $\begin{array}{c}\text { Incoming } \\
\text { shortwave } \\
\text { radiation }\end{array}$ & $\begin{array}{c}\text { Air } \\
\text { temperature }\end{array}$ & $\begin{array}{c}\text { Relative } \\
\text { humidity }\end{array}$ & Wind speed \\
& $\mathrm{W} \mathrm{m}^{-2}$ & ${ }^{\circ}$ & $\%$ & $\mathrm{~m} \mathrm{~s}^{-1}$ \\
\hline High energy & 324 & 8.8 & 80 & 3.5 \\
Medium energy & 231 & 5.8 & 77 & 2.8 \\
Low energy & 143 & 3.3 & 75 & 2.0 \\
\end{tabular}

assumed, due to uncertainty over the exact form of the relationship of $z_{\mathrm{t}}$ and $z_{\mathrm{e}}$ to $z_{0}$ (Moore, 1983; Braithwaite, 1995).

The Obukhov length scale, $L$, was calculated from:

$$
L=\frac{\rho c_{\mathrm{P}} u^{* 3} \overline{T_{\mathrm{C}}}}{k g Q_{\mathrm{S}}},
$$

where $\overline{T_{\mathrm{C}}}$ is the absolute temperature $(\mathrm{K})$ of the air between the surface and the measurement height (calculated as the mean of the air temperature at $2 \mathrm{~m}$ and the surface temperature) and $g$ is the gravitational acceleration $\left(\mathrm{m} \mathrm{s}^{-2}\right)$. The friction velocity, $u^{*}$, was calculated as follows:

$$
u^{*}=\frac{k u_{\mathrm{c}}}{\ln \left(\frac{z}{z_{0}}\right)+a_{\mathrm{M}}\left(\frac{z}{L}\right)} .
$$

The problem of needing a priori knowledge of the values of $Q_{\mathrm{S}}$ and $u^{*}$ before $L$ could be calculated was overcome by iteration (Munro, 1990). Initially, $Q_{\mathrm{S}}$ and $u^{*}$ were calculated for neutral conditions $z / L=0$, and these values are then used to obtain an initial estimate of $L$. This value was then re-substituted to obtain subsequent values of $Q_{\mathrm{S}}$ and $u^{*}$. This method normally converged in under ten iterations to give the values of $u^{*}, L$ and $Q_{\mathrm{S}}$.

\section{Input data}

The 1993 ablation season was defined as the period 21 May-12 September. Snow depth was measured at 30 sites across the glacier at the start of the 1993 ablation season. From these measurements the relationship of snow depth to elevation was defined, to calculate the initial snow depth (ISD) in metres in each cell:

$$
\mathrm{ISD}=0.005 h-11.9\left(r^{2}=86.1 \% ; P=99.99\right) .
$$

Hourly means of incoming shortwave radiation, rainfall and the $2 \mathrm{~m}$ height wind speed, temperature and humidity were recorded throughout the 1993 ablation season at the weather station. Regular measurements of surface lowering were made throughout the 1993 ablation season at 13 ablation stakes positioned along the glacier centre line at 2602$2988 \mathrm{~m}$ a.s.l. (Fig 1). These measurements were used to assess model accuracy in calculating the surface melt rate.

\section{"Weather-type" days}

In order that the impact of variation in $\alpha$ and $z_{0}$ on the surface energy balance could be examined independently from variation in meteorological conditions, meteorological input to the model was held constant on particular days. To facilitate this, three "weather types" were defined corresponding to "high", "medium" and "low" energy inputs to the glacier surface (referred to as high-, medium- and lowenergy weather conditions henceforth), based on the values of each meteorological variable recorded at the weather station in the 1993 ablation season. Twenty-four hourly frequency distributions (one for each hour of the day) were defined for each variable. The value of each meteorological variable was defined by the mean of its distribution under medium-energy weather conditions, and one standard deviation above and below the mean under high- and lowenergy weather conditions, respectively (Table 2). The use of values one standard deviation above and below the mean represented the range of typical meteorological conditions at the glacier, rather than extreme values. 


\section{Model runs}

Four separate energy-balance experiments were conducted corresponding to the four aims stated in the introduction.

1. The model was run from 21 May to 12 September 1993, and melt-rate values calculated in the 13 gridcells corresponding to the locations of the ablation stakes compared with the measured melt rates. In addition, the modelled period of snow cover from the start of the ablation season at each stake was compared with field measurements.

2. The model was run from the start of the ablation season, using meteorological data recorded at the weather station, to calculate the spatial variation of $\alpha$ and $z_{0}$ across the glacier on four days at 4 week intervals during the 1993 ablation season (30 May, 27 June, 25 July and 22 August). Output values of surface conditions and surface energy fluxes were produced for each day. On the four days in question the three types of weather conditions defined in Table 2 were used as meteorological input to the model.

3. Late-ablation-season snowfalls have greatest impact on the surface energy balance, due to the large area of exposed ice in the ablation area and the low $\alpha$ of the remaining winter snowpack. Hence, a late-summer snowfall was modelled. The model was run from the start of the ablation season to 22 August, to simulate the late-season distribution surface conditions. A snowfall event of $12 \mathrm{~cm}$ w.e., of similar magnitude to those experienced in recent summers on Haut Glacier d'Arolla (Brock, 1997), was then modelled. The temporal variations in $\alpha, z_{0}$ and surface energy fluxes on the day before and the 7 days following the snowfall event were calculated in cells corresponding to the lowest and highest ablation stakes (2602 and $2988 \mathrm{~m}$ a.s.l., respectively), representing the lower and upper ablation areas. Three different meteorological scenarios were modelled using the weather conditions defined in Table 2.

4. Mean daily values of $\alpha, z_{0}$ and each surface energy flux were calculated for the middle ablation stake $(H$ at 2877 m a.s.l.) between 21 May and 12 September. The results were examined in conjunction with meteorological conditions recorded at the weather station. The daily values were converted to 5 day means to smooth highfrequency variation and make seasonal trends clearer.

\section{RESULTS}

\section{Model validation}

The difference between modelled and measured mean daily ablation rates for all 13 stakes was just $0.4 \mathrm{~mm}$ w.e. $\mathrm{d}^{-1}$. This was a small fraction of the mean daily ablation rates which were in the range $22-42 \mathrm{~mm}$ w.e. $\mathrm{d}^{-1}$. This error would result in only a slight overestimate of about $0.05 \mathrm{~m}$ w.e. melt over an entire ablation season for total ablation in the range $2.5^{-}$ $4.8 \mathrm{~m}$ w.e. melt.

However, the rms of the difference between modelled and measured ablation rates was $3.1 \mathrm{~mm}$ w.e. $\mathrm{d}^{-1}$. This suggests that the surface melt rate is either under- or overestimated at individual stakes, but these errors tend to cancel each other out when a number of stakes are examined. Such variance is unsurprising, however, given that the measured melt rates are essentially point values, whereas the model

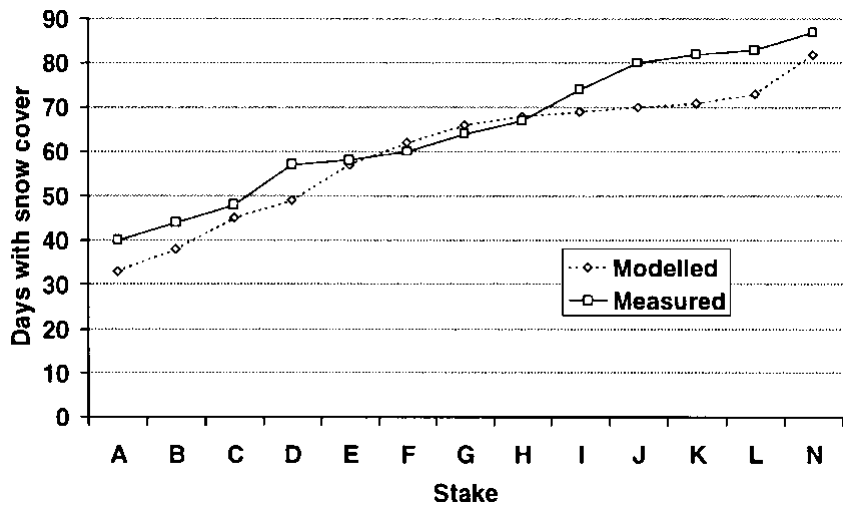

Fig. 4. Modelled and measured days of snow cover from start of ablation season at centre-line stakes.

calculates the melt rate for a $20 \mathrm{~m} \times 20 \mathrm{~m}$ area. Field studies have demonstrated that measurements of surface lowering at ablation stakes generate highly spatially variable surface melt values, and that several ablation stakes are required to generate accurate surface melt-rate values (Braithwaite and others, 1998). Thus, overall the updated model performed very well.

Further confirmation of the model's performance can be seen from the accuracy with which the number of days of snow cover from the start of the season at each stake was calculated (Fig. 4). Generally, the modelled snow-cover period was within a few days of the measured snow-cover period, and at most the discrepancy was 10 days. This result is all the more impressive considering it was assumed that all snow had a density of $500 \mathrm{~kg} \mathrm{~m}^{-3}$ (the mean measured value), and thus snow-density variation with depth in the winter snowpack was ignored. Furthermore, the scale difference between ablation stakes and model cells could also create differences between modelled and actual snow-cover periods of a few days. Such accurate modelling of snowline retreat is crucial for investigation of seasonal and spatial patterns in the surface energy balance due to the large contrast between $\alpha$ and $z_{0}$ on snow and ice surfaces.

It should be noted, however, that accurate calculation of the surface melt rate does not necessarily indicate that each component of the surface energy balance was modelled accurately, since errors in the calculation of individual fluxes may have cancelled out. While direct measurements of the individual energy fluxes on the glacier were not available for comparison, the likely error range in each flux can be estimated. The pyranometer accuracy was $\pm 1 \%$, so net shortwave radiation flux errors were dependent on the accuracy of the $\alpha$ parameterizations, for which the rms errors are given in Table 1. The assumption that the surface was always melting could have resulted in an overestimate of the net longwave radiation flux. For example, the overestimate would be $6.6 \%$ for a surface temperature of $-5^{\circ} \mathrm{C}$. Air temperature was recorded to an accuracy of $\pm 0.1^{\circ} \mathrm{C}$, so uncertainty in the incoming longwave radiation flux was dependent on errors in the estimation of cloud-cover amount. For a $\pm 20 \%$ error in cloud cover the resulting error in incoming longwave radiation is $\pm 4 \%$. The turbulent-flux calculation was sensitive to a number of uncertainties which could have occurred in extrapolating point meteorological measurements at the weather station to the entire glacier. For wind-speed and temperature errors of $\pm 20 \%$ the uncertainty in the turbulent fluxes is in the range $30-40 \%$. The turbulent fluxes were 

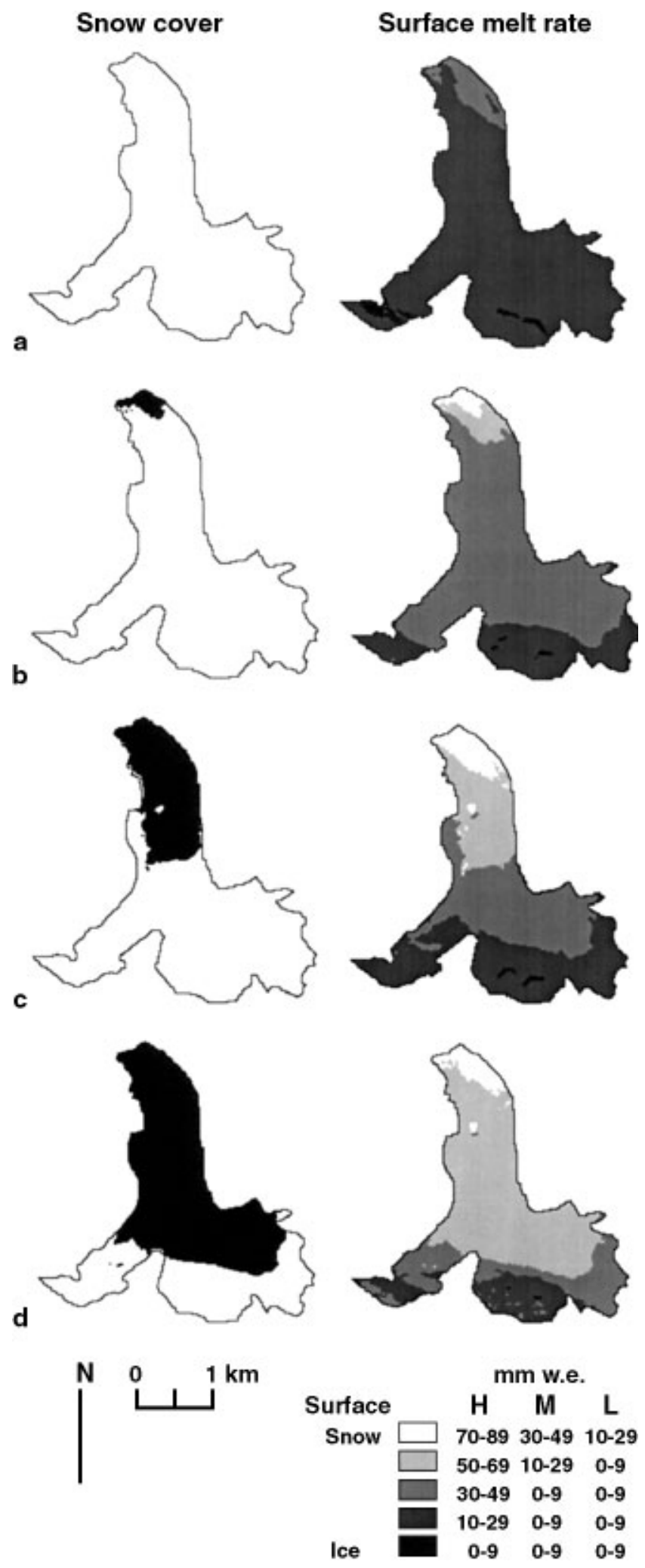

Fig. 5. Spatial variation of snow cover (column 1) and the surface melt-rate flux (column 2) across Haut Glacier d'Arolla on (a) 30 May, (b) 27 Fune, (c) 25 Fuly and (d) 22 August 1993. Total daily fluxes under high- (H), medium( $M)$ and low- $(L)$ energy weather types are given.

also dependent on the accuracy of the $z_{0}$ parameterizations. The $z_{0}$ ranges for smooth snow, rough snow and ice in the updated model result in a further variation of $15-25 \%$ in the turbulent fluxes. However, the close correspondence between measured and calculated ablation over the 1993 ablation season suggests that errors in individual flux calculations are smaller than these maximum estimates.

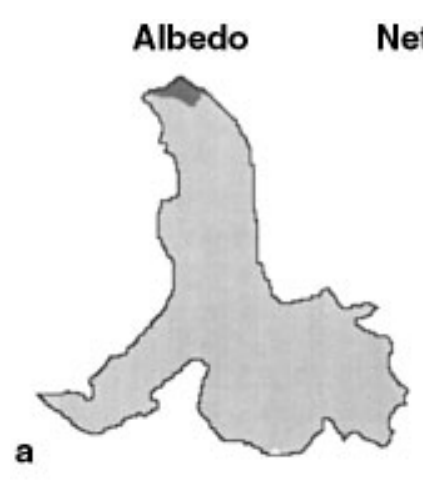

Net shortwave radiation flux
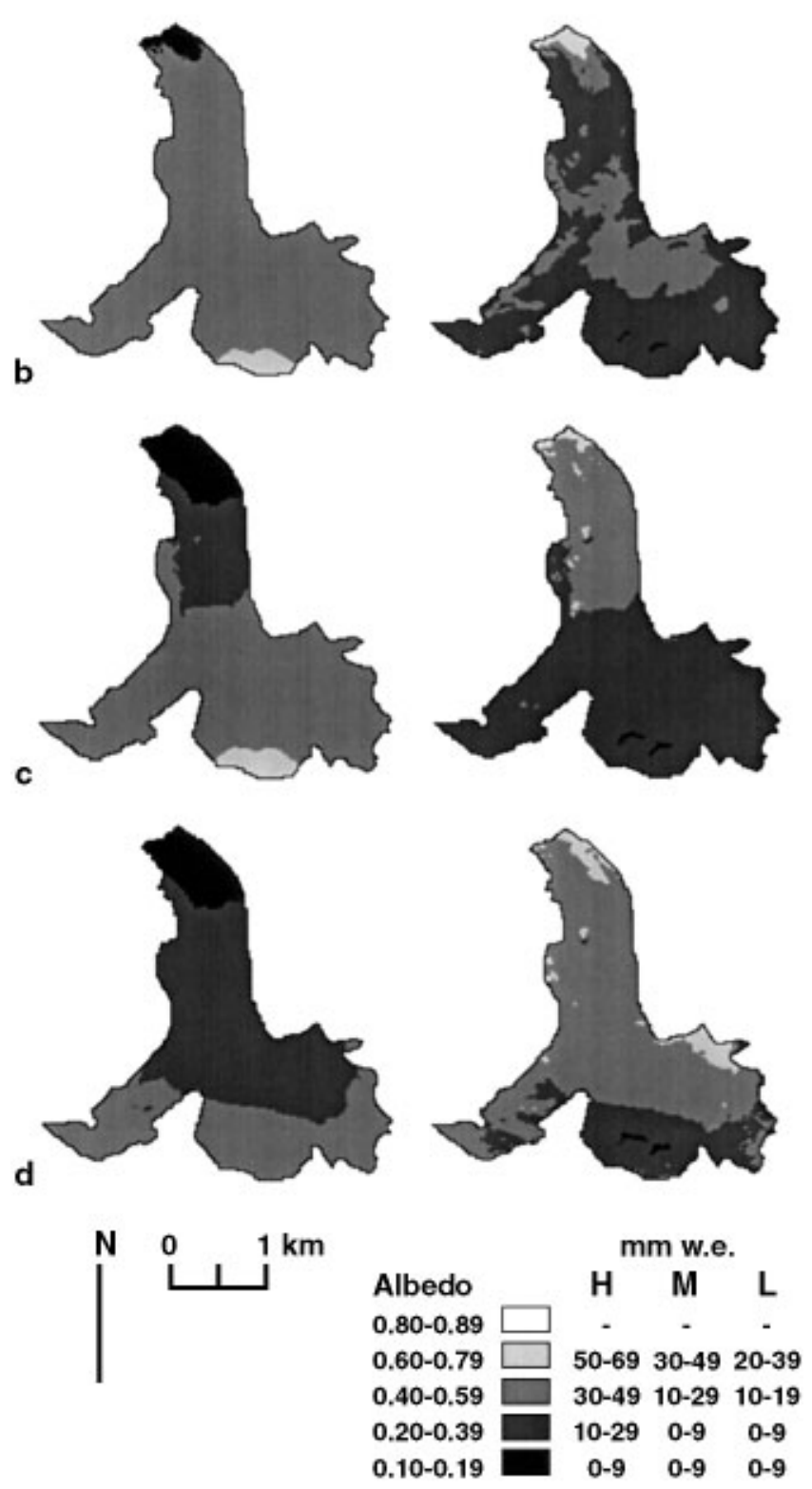

Fig. 6. Spatial variation of albedo (column 1) and the net shortwave radiation flux (column 2) across Haut Glacier d'Arolla on (a) 30 May, (b) 27 Fune, (c) 25 Fuly and (d) 22 August 1993. Total daily fluxes under high- $(H)$, medium$(M)$ and low- $(L)$ energy weather types are given.

Spatial and temporal patterns in surface energy balance during 1993 ablation season

Maps of the spatial variation of snow cover, $\alpha, z_{0}$ and the net shortwave, turbulent and surface melt fluxes across Haut Glacier d'Arolla on four days in the 1993 ablation season are shown in Figures 5-7. Flux values are quoted in units of 

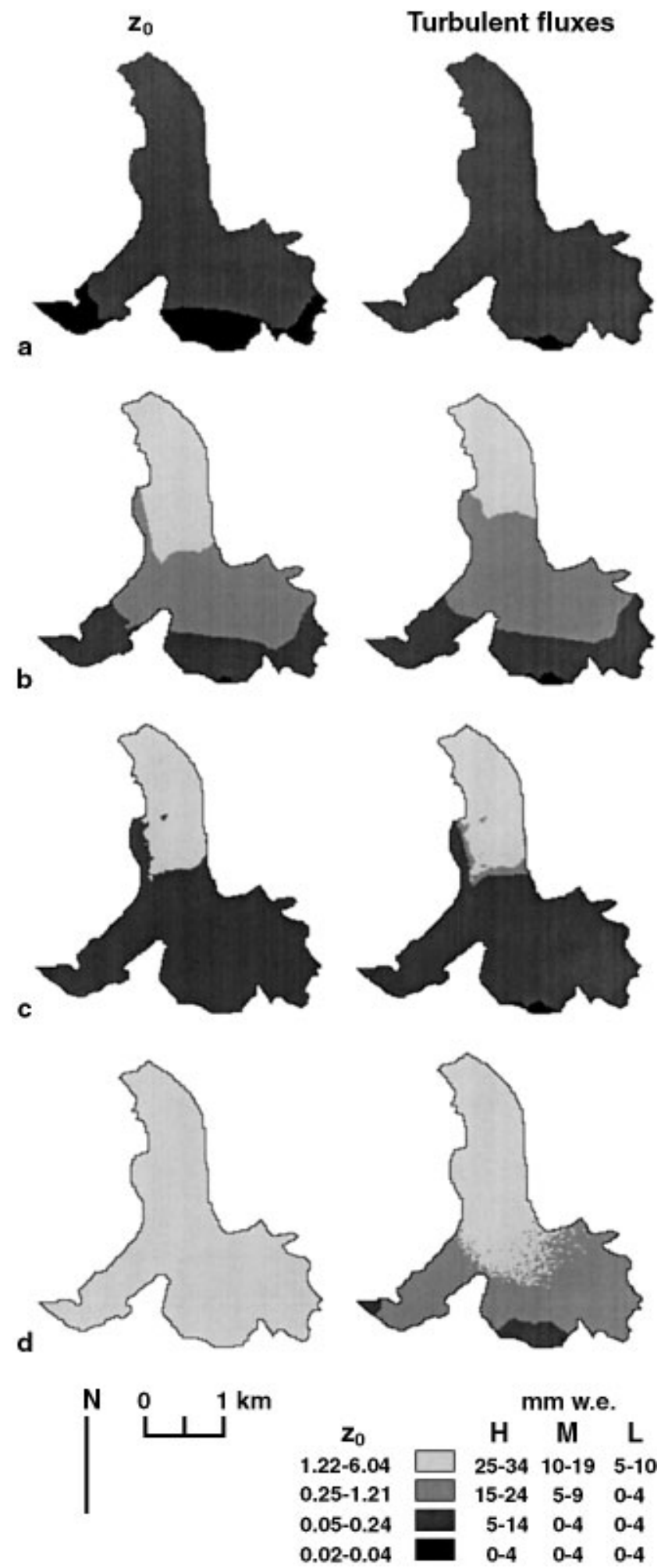

Fig. 7. Spatial variation of aerodynamic roughness length (column 1) and the turbulent sensible- and latent-heat fluxes (column 2) across Haut Glacier d'Arolla on (a) 30 May, (b) 27 Fune, (c) 25 Fuly and (d) 22 August 1993. Total daily fluxes under high- $(H)$, medium- $(M)$ and low- $(L)$ energy weather types are given.

mm w.e. melt under high-, medium- and low-energy weather conditions. The net shortwave flux was the main contributor to surface melt, being typically twice that of the turbulent fluxes under high-energy conditions, and increasing to three or even four times that of the turbulent fluxes under lowenergy conditions. The main patterns of variation in the surface energy balance were as follows:
1. The position of the transient snowline was of great importance to the surface energy balance as it marked the boundary between relatively high melt rates on ice and low melt rates on snow (Fig. 5). As the ablation season progressed and the transient snowline retreated up-glacier, an increasingly large area of the glacier experienced high melt rates. The difference in melt rates on snow and ice was largely explained by the spatial pattern of $\alpha$ and the net shortwave radiation flux (Fig. 6). The spatial patterns of $z_{0}$ and turbulent flux variation, however, were largely independent of the position of the snowline (Fig. 7). Over the glacier tongue in late June and across the entire glacier in late August, snow and ice had similar $z_{0}$ values. The exception was late July (Fig. 7c), when, because recent snowfalls had reduced the $z_{0}$ roughness of the winter snowpack, there was a large contrast with the rough glacier ice down-glacier.

2. Temporal changes in $\alpha$ and $z_{0}$ associated with the metamorphism and melting of the winter snowpack had an important impact on the surface energy balance. In particular, the decrease in $\alpha$ of about 0.10 between late May and late June resulted in a large increase in the net shortwave radiation flux (Fig. 6a-b). Similarly, the increase in $z_{0}$ over the same period, from about $0.1 \mathrm{~mm}$ to $>1.0 \mathrm{~mm}$ over a large part of the glacier tongue, resulted in a doubling of turbulent flux magnitude over snow (Fig. $7 \mathrm{a}$ and $\mathrm{b}$ ). Towards the end of the ablation season, snow $\alpha$ was similar to that for ice, so the contrast in the net shortwave flux between snow and ice became less marked as the ablation season progressed (Fig. 6). Similarly, snow $z_{0}$ increased to values comparable to those of ice $z_{0}$ in late August (Fig. 7d).

3. Albedo tended to increase with elevation (Fig. 6). On snow this was because the increases in grain-size and impurity concentration in the snowpack, which reduce $\alpha$, proceeded more slowly at low temperatures at high elevations. On ice, $\alpha$ decreased down-glacier due to increasing surface dust and debris. Hence, the spatial patterns of the net shortwave radiation and melt fluxes were dominated by down-glacier increases at each stage of the season (Figs 5 and 6). The effects of slope and aspect on the net shortwave and melt fluxes were superimposed on this overall trend. The effect was most noticeable on the north-facing slopes of the upper accumulation area (Figs 5 and 6). Shading also reduced the net shortwave and melt fluxes over the western side of the glacier tongue (e.g. Figs $5 \mathrm{~d}$ and $6 \mathrm{~d}$ ).

The $z_{0}$ decreased up-glacier in late May, June and July and this pattern was very marked in June (Fig. 7). This was because the development of ablation hollows on the snow surface proceeded more slowly at higher elevations due to lower melt rates. By the end of the ablation season the spatial variation of snow $z_{0}$ was small, as in late May when ablation hollows were initiating. Overall, the spatial variation of the turbulent fluxes reflected the pattern of $z_{0}$ variation combined with the decrease in air temperature, and to a lesser extent air pressure, with increasing elevation.

4. The impact of $\alpha$ and $z_{0}$ on the surface energy balance was very large under high-energy weather conditions, but under low-energy conditions their impact, in particular that of $z_{0}$, on the spatial variation in surface energy fluxes was small (Figs 5-7). 

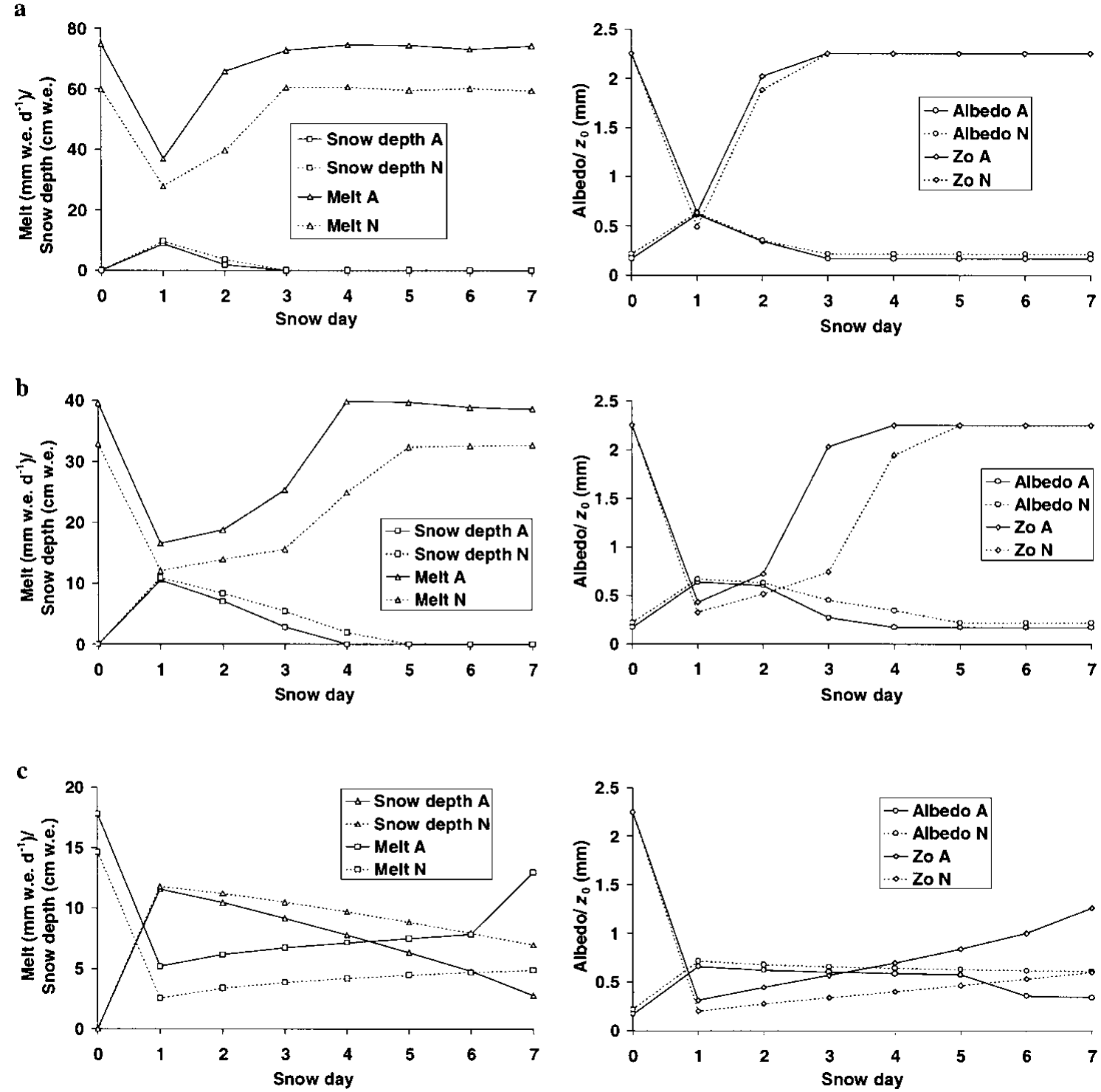

Fig. 8. Temporal variation of snow depth and surface melt rate (column 1) and albedo and aerodynamic roughness length (column 2) at stake $A$ (2602 $m$ a.s.l.) and stake $\mathcal{N}(2988 m$ a.s.l.) before and after a late-summer snowfall of initial depth $12 \mathrm{~cm}$ w.e. under (a) high-, (b) medium-and (c) low-energy weather types. In each case the snowfall occurred at $0001 \mathrm{~h}$ on snow day 1.

\section{Impact of the simulated summer snowfall}

The melt rate was dramatically reduced by $>50 \%$ from the pre-snowfall values (snow day 0) on the day of the snowfall (snow day 1) (Fig. 8). These changes were caused by the increase in $\alpha$ to $>0.70$ and the decrease in $z_{0}$ to $\leq 0.5 \mathrm{~mm}$ associated with the snowfall.

Whereas $\alpha$ increased to values comparable to the early ablation season, $z_{0}$ did not reduce to early-season values $(\leq 0.1 \mathrm{~mm})$ due to the influence of underlying ice-roughness elements. Consequently, the net shortwave radiation and turbulent fluxes made similar-magnitude contributions to the melt rate immediately following the snowfall.

The impact of the snowfall on the surface energy fluxes was short-lived when energy input to the surface was high, and pre-snowfall values were resumed 3 days after the snowfall (Fig. 8a). Under medium-energy conditions the surface energy fluxes were affected by the snowfall for 3 days in the lower ablation area (stake A) and 4 days in the upper ablation area (stake $\mathrm{N}$ ), but the melt rate climbed steadily in this period in response to decreasing snow $\alpha$ and increasing snow $z_{0}$ (Fig. 8b). An important contrast occurred under low-energy conditions. Here snow remained lying in both upper and lower ablation areas throughout the 7 day period following the snowfall, and the melt rate was very slow to recover to its pre-snowfall level (Fig. 8c). Clearly, meteorological conditions following a summer snowfall event are of great importance in determining the length of time surface melt rates are suppressed. Under low-energy-input, i.e. cool and cloudy, conditions, the slow change in $\alpha$ and $z_{0}$, due to sluggish metamorphism and melt of the snow cover, was instrumental in causing the snow cover to persist.

The contrast between energy fluxes in the lower and upper ablation areas following the snowfall was small under high- and medium-energy weather conditions, but under low-energy weather conditions the melt rates diverged with increasing time after the snowfall due to the more rapid changes in $\alpha$ and $z_{0}$ in the lower ablation area (Fig. 8).

Seasonal trends in albedo, aerodynamic roughness length, meteorological conditions and energy fluxes during 1993 ablation season

The single most important event during the ablation season was the transition from snow to ice with the abeyance of the winter snowpack, which occurred at the end of July at stake 
a

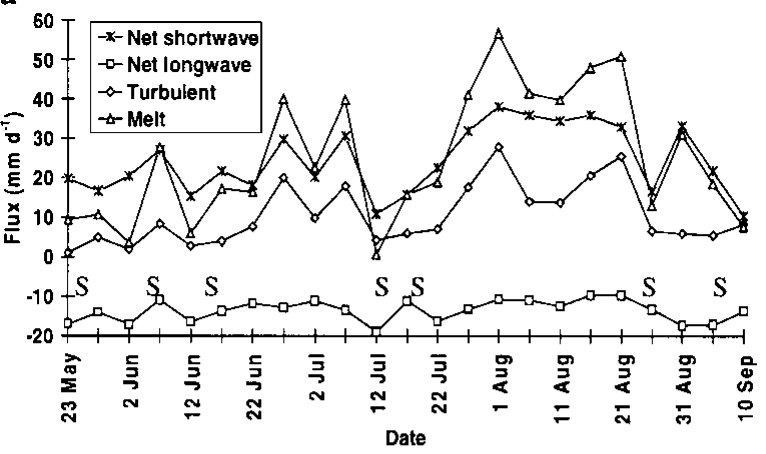

b
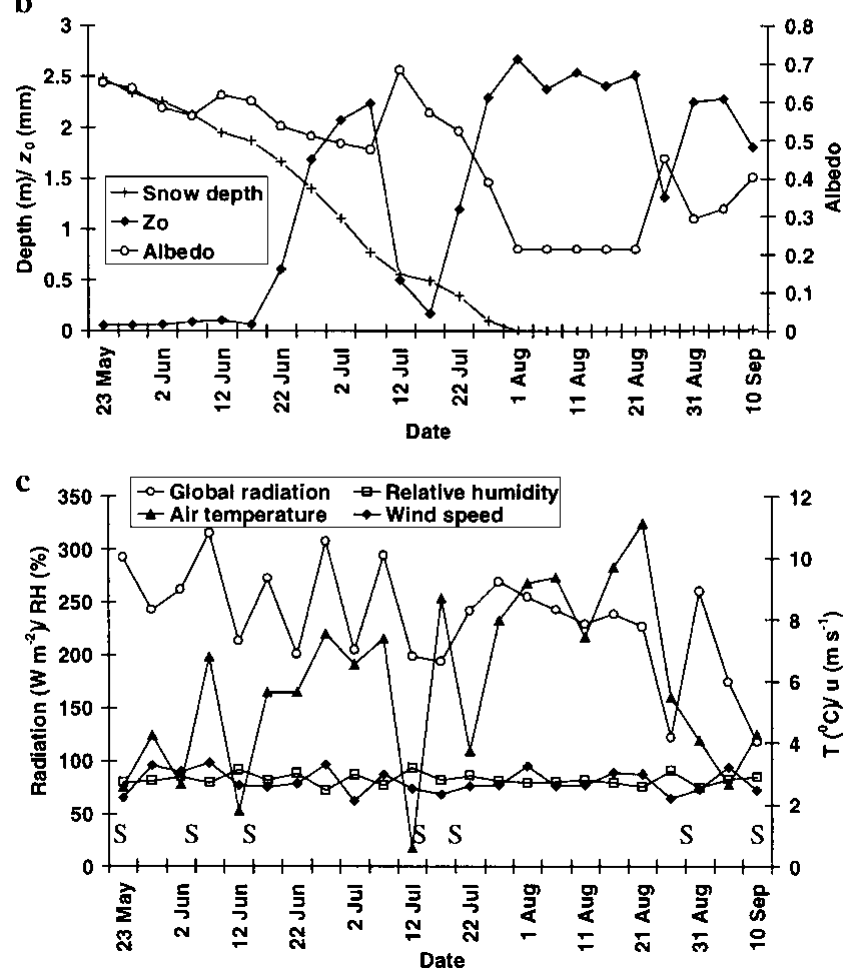

Fig. 9. Five-day means of ( a) surface energy fluxes and ( $b$ ) surface conditions at stake $H$ (2877 $m$ a.s.l.), and (c) meteorological conditions at the automatic weather station during the 1993 ablation season. S indicates the dates of the main summer snowfall events.

H (Fig. 9). Thus, the highest values of the net shortwave, turbulent and melt energy fluxes occurred in the first 3 weeks of August, while $\alpha$ was low and $z_{0}$ high, but prior to the decline in global radiation and temperature values with the onset of the accumulation season.

The decrease of $\alpha_{\mathrm{S}}$ in May and June was gradual compared with the rapid decrease which occurred with the final wastage of the winter snowpack in the second half of July (Fig. 9b). Snow $z_{0}$ remained very low until mid-June, when a very rapid increase to $>2 \mathrm{~mm}$ began (Fig. $9 \mathrm{~b}$ ). These surface factors controlled the temporal variation of the shortwave and turbulent fluxes, respectively. In particular, the turbulent fluxes were suppressed at values of $<10 \mathrm{~mm} \mathrm{~d}^{-1}$ until the second half of June (Fig. 9a).

The impact of summer snowfalls was very pronounced (Fig. 9). A heavy snowfall in mid-July had a particularly large and sustained impact on the energy balance, but the increases in $\alpha$ and decreases in $z_{0}$ and surface energy fluxes resulting from snowfalls in mid-June, late August and early September were also very marked. It was also apparent that, as well as a decrease in temperature, these snowfall events were characterized by a large drop in global radiation values (Fig. 9c). The three lowest values of global radiation in Figure 9 each coincided with summer snowfall events, suggesting that the snowfalls occurred during periods of sustained cloud cover. This might be explained by particularly active weather fronts or intense cyclonic conditions. The combination of low global radiation and air temperatures could have prolonged the impact of summer snowfall events on the surface melt rate, based on the findings in the previous section.

\section{DISGUSSION AND GONGLUSIONS}

We have used a semi-distributed physically based energy model to examine the impact of variations in $\alpha$ and $z_{0}$ on the surface energy balance of a small valley glacier over the course of an ablation season. Some key outcomes from the study are as follows:

1. With high-quality input data (accurate DTMs, local meteorological measurements) current energy-balance theory enables the melt rate of snow and ice to be calculated accurately across a glacier and permits investigation of spatial and temporal patterns in the surface energy balance. However, some limitations on the transferability of this result might be that: (i) the energy balance was generally positive over the period and area considered in this study, so conduction of heat into the surface of the glacier was negligible; (ii) suitable parameterizations to calculate spatial and temporal variations in $\alpha$ and $z_{0}$ were available and had been calibrated locally; and (iii) the energy balance was dominated by shortwave radiation receipts which can be monitored accurately with a pyranometer, knowledge of slope and aspect variations and an $\alpha$ parameterization scheme. At glaciers where turbulent and longwave fluxes play a greater role, measurement difficulties may lead to larger errors in surface melt calculations.

2. Accurate modelling of the up-glacier migration of the transient snowline is critical to accurate calculation of spatial patterns in, and the total volume of, surface melt. Changes in $\alpha$ and $z_{0}$ which occur during the melt of the winter snowpack must be parameterized accurately to enable calculation both of temporal variations in the surface melt rate on the winter snowpack and of the changing position of the transient snowline during the ablation season. This is best achieved using parameterizations which are linked to physical changes in the snow (e.g. grain-size increases and ablation-hollow formation), and which are also responsive to the important changes in $\alpha$ and $z_{0}$ which occur during summer snowfall events.

3. Summer snowfall events are of great importance to the summer energy balance and should be accounted for in melt models and calculations of the mass-balance response of glaciers to climate change. The persistence of the fresh snow cover and suppression of surface melt rates is greatly increased when (meteorological) energy inputs to the surface are low. Examination of meteorological data for the 1993 ablation season revealed that summer snowfall events were usually associated with periods of cool, cloudy conditions. This could, to some degree, offset the increase in glacier ablation caused by global warming, if trends towards increasing precipita- 
tion and cloudiness under climatic-change scenarios are realized (Houghton and others, 1996).

4. The representativeness of the findings should be tested at other sites. The importance of variation in the longwave radiation fluxes, which are estimated by the model, to the surface energy balance should be investigated, particularly at sites with a high incidence of cloud and mist. The applicability of the $\alpha$ and $z_{0}$ parameterizations should be investigated at other sites and, if possible, extended to calculate variations of these properties on glacier ice.

\section{ACKNOWLEDGEMENTS}

This work was undertaken while B.W. Brock was in receipt of U.K. Natural Environment Research Council (NERC) studentship GT4/92/5/P; additional funding was provided by NERC grant GT3/8114, and the weather station was borrowed from the NERC equipment pool. The original energy-balance model was developed under NERG grant GR3/7004A. We are grateful to all members of the 1992-94 Arolla Glaciology Project, in particular B. Hubbard, M. Nielsen and the Cambridge University undergraduates who helped with the fieldwork. We also thank Grande Dixence SA, Y. Bams and P. and B. Bournissen for their logistical assistance. M.V. Anzevui kindly permitted us to camp at the field site. J. Ford is thanked for cartographical assistance with Figure 1. K. Steffen and two anonymous referees are thanked for their helpful comments which improved this paper.

\section{REFERENCES}

Arnold, N. S., I. C. Willis, M. J. Sharp, K. S. Richards and W. J. Lawson. 1996. A distributed surface energy-balance model for a small valley glacier. I. Development and testing for Haut Glacier d'Arolla, Valais, Switzerland. 7. Glaciol., 42(140), 77-89.

Arnold, N., K. Richards, I. Willis and M. Sharp. 1998. Initial results from a semi-distributed, physically-based model of glacier hydrology. Hydrol. Processes, 12(2), 191-219.

Braithwaite, R. J. 1995. Aerodynamic stability and turbulent sensible-heat flux over a melting ice surface, the Greenland ice sheet. f. Glaciol., 41 (139), 562-571.

Braithwaite, R. J. and O. B. Olesen. 1990. A simple energy-balance model to calculate ice ablation at the margin of the Greenland ice sheet. F. Glaciol., 36(123), 222-228.

Braithwaite, R. J., T. Konzelmann, C. Marty and O. B. Olesen. 1998. Errors in daily ablation measurements in northern Greenland, 1993-94, and their implications for glacier climate studies. f. Glaciol., 44(148), 583-588.

Brock, B.W. 1997. Seasonal and spatial variations in the surface energy-balance of valley glaciers. (Ph.D. thesis, University of Cambridge.)

Brown, G. H., M. J. Sharp, M. Tranter, A. M. Gurnell and P.W. Nienow. 1994. Impact of post-mixing chemical reactions on the major ion chemistry of bulk meltwaters draining the Haut Glacier d'Arolla, Valais, Switzerland. Hydrol. Processes, 8(5), 465-480.

Dyer, A. J. 1974. A review of flux-profile relationships. Boundary-Layer Meteorol., 7, 363-372.

Escher-Vetter, H. 1985. Energy balance calculations for the ablation period 1982 at Vernagtferner, Oetztal Alps. Ann. Glaciol., 6, 158-160.

Harbor, J., M. Sharp, L. Copland, B. Hubbard, P. Nienow and D. Mair. 1997. The influence of subglacial drainage conditions on the velocity distribution within a glacier cross section. Geology, 25(8), 739-742.

Hay, J. E. and B. B. Fitzharris. 1988. A comparison of the energy-balance and bulk-aerodynamic approaches for estimating glacier melt. f. Glaciol., 34(117), 145-153.

Hock, R. and C. Noetzli. 1997. Areal melt and discharge modelling of Storglaciären, Sweden. Ann. Glaciol., 24, 211-216.

Houghton, J. T., L. G. Meira Filho, B. A. Callander, N. Harris, A. Kattenberg and K. Maskell, eds. 1996. Climate change 1995: the science of climate change. Cambridge, etc., Cambridge University Press.

Hubbard, B. P., M. J. Sharp, I. C. Willis, M. K. Nielsen and C. C. Smart. 1995. Borehole water-level variations and the structure of the subglacial hydrological system of Haut Glacier d'Arolla, Valais, Switzerland. F. Glaciol., $41(139), 572-583$.

Lang, H. 1986. Forecasting meltwater runoff from snow-covered areas and from glacier basins. In Kraijenhoff, D. A. and J. R. Moll, eds. River flow modelling and forecasting. Dordrecht, D. Reidel Publishing Co., 99-127. (Water Science and Technology Library.).

Lettau, H. 1969. Note on aerodynamic roughness-parameter estimation on the basis of roughness-element description. 7. Appl. Meteorol., 8, 828-832.

Moore, R.D. 1983. On the use of bulk aerodynamic formulae over melting snow. Nord. Hydrol., 14(4), 193-206.

Munro, D. S. 1990. Comparison of melt energy computations and ablatometer measurements on melting ice and snow. Arct. Alp. Res., 22(2), 153-162.

Munro, D. S. and G. J. Young. 1982. An operational net shortwave radiation model for glacier basins. Water Resour. Res., 18(2), 220-230.

Oerlemans, J. 1992. Climate sensitivity of glaciers in southern Norway: application of an energy-balance model to Nigardsbreen, Hellstugubreen and Alfotbreen. 7. Glaciol., 38(129), 223-232.

Oerlemans, J. 1993. A model for the surface balance of ice masses. Part 1. Alpine glaciers. Z. Gletscherkd. Glazialgeol., 27-28, 1991-1992, 63-83.

Oerlemans, J. and J. P. F. Fortuin. 1992. Sensitivity of glaciers and small ice caps to greenhouse warming. Science, 258(5079), 115-117.

Richards, K. S. and 9 others. 1996. An integrated approach to modelling hydrology and water quality in glacierized catchments. Hydrol. Processes, 10 (4), 479-508.

Röthlisberger, H. and H. Lang. 1987. Glacial hydrology. In Gurnell, A. M. and M.J. Clark, eds. Glacio-fluvial sediment transfer: an alpine perspective. Chichester, etc., John Wiley and Sons, 207-284.

Willis, I. and J.-M. Bonvin. 1995. Climate change in mountain environments. Geography, 80 (348), Part 3, 247-261. 